\title{
Vetenskapens gärdsgårdar och slutna rum - Ett bidrag till en förruttnelseprocess och ett nybygge
}

\author{
Av Jonny Nilsson och Kenneth Strömberg, doktorander i historia
}

Länk till presentation av Jonny Nilsson

Länk till presentation av Kenneth Strömberg

- Sökandet efter mening(sfullhet)

- Myten om det pluralistiska forskarsamhället

- En kunskapsteoretisk utgångspunkt

- Humanioras profetiska uppgift

- Phronesis

- Avslutning

\section{Sökandet efter mening(sfullhet)}

De flesta av oss som är verksamma inom humaniora på Högskolan i Växjö kan inte öppna fönstren i våra arbetsrum eftersom de saknar traditionella handtag. I ivern att tillämpa den nya ventilationstekniken har man inte tagit hänsyn till och värderat den tillfredsställelse som det innebär att själv få öppna ett fönster och andas in den friska luften efter ett sommarregn. Den instrumentella rationaliteten (vem nu det är) fick företräde framför det som många utav oss säkert hade värderat högre.

Efter några år som doktorander i historia har det mognat fram en förhoppningsvis konstruktiv frustration som hämtar sin näring i en tilltagande känsla av att leva i ett instängt svenskt forskarrum (att skriva "forskarvärld" vore helt missvisande) där man inte riktigt på allvar orkar diskutera sina egna grundvalar och sina tänkbara uppgifter i samhället. I många andra länder pågår en debatt som är långt mer livlig, där man vågar stanna upp och reflektera över den egna rollen och samhällsuppgiften. En orsak till den svenska tafattheten kan, förutom svenskens konfliktundvikande och källkritiskt neutralneurotiska sinnelag, vara att nationens humanioraforskning är så liten att den ryms i ett rum, och den som vågar krossa ett fönster för att släppa in lite ny luft blir ofta utkastad genom samma fönster av de som har hunnit markera sina revir i rummet. Fönstret spikas sedan igen och det dröjer innan någon dristar sig till att försöka igen. Alla andas samma luft, leker, träter och försonas i samma rum. Och så länge man stannar där och följer spelets regler riskerar man inte sin akademiska karriär eller den bekräftelse som vi människor behöver för att vara tillfreds med livet. Samtidigt skapar det konflikter för den som då måste kompromissa med sin övertygelse och göra våld på sin identitet. Till slut måste den människa som strävar efter ett uns av ärlighet gentemot sig själv och andra ställa sig frågan om den egna forskningen betyder någonting utöver jaget som jagar vidare i karriärens eviga "snart- och nästa-lek".

Syftet med denna debattartikel är inte att tala illa om våra äldre vänner och kollegor inom humaniora, utan att diskutera hur forskningen skulle kunna nå en högre grad av meningsfullhet än vad som idag är fallet. Vi söker en meningsfullhet som sträcker sig förbi jaget och vetenskapens gärdsgårdar - gärdsgårdar som genom fernissa kanske fortfarande ser ut att stå stadigt, men där det i träets inre länge har pågått en förruttnelseprocess. Det är inte troligt, eller ens önskvärt, att någon kommer att riva gärdsgården och göra vetenskaplig revolution, men om vi kan vill vi bidra till förruttnelseprocessen, försöka öppna några fönster och ge inspiration till en fortgående förnyelse av humaniora som vetenskapsfält. Ehuru vår artikel äger aktualitet för hela humaniora, gör vi inte anspråk på 
att kunna överblicka hela fältet, inte ens vårt eget ämne, men naturligt nog har artikeln en slagsida åt historia eftersom vi är historiker.

Det är tid att vitalisera vetenskapen så att den kommer mer i kontakt med människors levnadsvillkor, både i dess existentiella mening och vad gäller praktiskt vardagsliv. Av skäl vi snart skall komma in på har mycket av dagens vetenskap varken kontakt med himlen eller marken. För att en förändring skall kunna ske måste fler våga spränga de gränser och de tabun som idag är förhärskande. Hur skall en vetenskap som humaniora kunna säga något relevant och meningsfullt om människan om den inte tar hänsyn till existentiella och praktiskt etiska och moraliska problem? Humaniora borde inte kunna särskiljas från de filosofiskt/teologiskt präglade frågorna om människans ursprung, natur och existens, frågor om Gud, rätt och fel, ont och gott, vardagslivets konkreta glädje, komplikationer och mysterier. Det är möjligt att barnet i mammans livmoder upplever rädsla när det skall födas - det är ju så varmt och tryggt i mammas mage - men väl ute så öppnar sig en ny värld med nya möjligheter - och risker. Tänk om vi skulle våga lämna livmodern, ta risken, höja och vidga blicken, istället för att självbelåtet slänga ur oss tröttsamma klichéer om det pluralistiska forskarsamhället.

\section{Myten om det pluralistiska forskarsamhället}

Allt som oftast hörs det röster som säger att forskarsamhället är pluralistiskt och vidsynt, precis som om det vore en självklarhet bara för att humaniora vill skylta med en humanistisk hållning. Man har då åsyftat en förekommande bredd vad gäller ämnen och teorier. Låt vara att det finns en viss pluralism innanför de gärdsgårdar som forskarsamhället har satt upp, men de accepterade teorierna och metoderna återspeglar i mycket de ideologier som har varit dominerande på 1900-talet och som har sina rötter i den vetenskap och de idéer som föds under renässansen och upplysningen. Detta innebär med automatik en uteslutning av många alternativa synsätt. Det finns en hämmande majoritetskonsensus om vilka teorier och metoder som skall tolereras och vilka som inte skall det. Med Thomas Kuhns ord skulle vi kunna tala om ett paradigm som lägger fast de "riktiga" vetenskapliga förklaringsgrunderna och relevanta frågeställningarna, en slags mer eller mindre oskrivna spelregler, som samlar ett forskarkollektiv kring en bestämd problemlösande vetenskaplig praxis. Trots en ständig förnyelse, teoretisk medvetenhet och flera nya ämnen och infallsvinklar sedan 1960-talet, trots den postmoderna utmaningen, finns fortfarande en självgod uppfattning inom humaniora om vad som är det enda rätta. Ännu finns det många som verkar tro att människan är förmögen att fånga det objektiva och hela sanningen i en liten ask. Fortfarande befäster man de konstgjorda gränserna gentemot det man kallar metafysik och värderingar.

Det är vår mening att denna mänskliga hybris, som bland annat har tagit sig uttryck i objektivitetsideal och en överdriven åtskillnad mellan så kallad "säker kunskap" och tro, har gjort mer skada än nytta och på sikt kommit att förpassa humaniora till en snäll, anpassad och integrerad del av samhällsutvecklingen. Men finns det egentligen någon kunskapsteoretiskt eller etiskt hållbar grund för de gränser som en majoritet av forskarna sätter upp? Om inte, vilka konsekvenser bör vi då dra?

\section{En kunskapsteoretisk utgångspunkt}

Den moderna vetenskapen bygger, trots dess betoning på kritik, på en enorm tilltro till människans förmåga att nå objektiv säker kunskap som sedan är tänkt att tillämpas för att skapa ett allt bättre eller i värsta fall - utifrån en specifik ideologi - ett perfekt samhälle. Vi skulle kunna kalla detta för humanism. Utifrån denna falska förhoppning om människan har man sedan dragit upp gränser mellan tro och vetande på ett sätt som har skadat kreativitet och forskarglädje i flera hundra år vid det här laget.

Humanismen utvecklades i modern tid främst av upplysningstidens filosofer i Frankrike, även om den har sina rötter i den antika grekiska filosofin - ursprunget står väl egentligen 
att finna redan i Edens lustgård där människan lyckades rasera sitt paradis genom att sätta sig själv i centrum. "En av de första frukterna av den moderna humanismen var den franska revolutionen. Under ropet "frihet, jämlikhet och broderskap" ställde man upp sina giljotiner och avrättade den franska adeln och kungahuset", skriver den kristne läkaren Sven Reichman i samband med att han kritiskt analyserar den moderna humanismen.[1] Det anmärkningsvärda var inte att grupper som missbrukade sin makt fick skörda det man sått. Men det originella var att upprorsgrupperna hade med sig en godhetens filosofi som legitimerade beteendet. Olika varianter av denna humanism genomsyrar idag de flesta politiska ideologier i västvärlden. Reichman gör en helt riktig iakttagelse när han påstår att "Om något har blivit en sorts självklarhetens "så här är det ju" i vår kultur och vår tid, så är det humanismen och dess rättfärdighetsideal."[2] Ordet humanism kommer av det latinska ordet "homo" som betyder människa. Humanismen är alltså läran om människan och systemets fasta punkt är människans förnuft. Människan har förnuft och är förnuftig, menar man. "Eftersom godhet är mera förnuftigt än ondska, så antar man, att människan kommer att välja det goda och riktiga, om man bara informerar henne. Därför anses människan i princip också vara god."[3]

Det behövs inte mycket insikt i historien för att inse att denna människosyn är ohållbar. Människan har förvisso ett förnuft, men har en otäck tendens att agera oförnuftigt, även sedan hon blivit informerad. Det är detta som enligt kristendomen är synd. Människan hade redan i lustgården fått information om det goda och det rätta, men valde ändå en annan väg. "Problemet är att förnuftet inte är högsta instans i människans liv, utan begäret", skriver Sven Reichman och fortsätter "I oss själva är vi alla som alkoholisten. Regnar det, så dricker han för att trösta sig. Är vädret vackert så måste man fira det med en sup."[4]

Kunskaper kan missbrukas om vi inte lever efter en princip som går ut på tjänande och offervilja. Den mänskliga visheten är ett maktinstrument. Så länge mänskligheten försöker skapa den goda världen utan Guds kärleksfulla vishet kommer vi tyvärr att inte bara få se en Moder Theresa, utan också en Stalin, Mao eller Hitler, katastrofala sociala projekt, massmord och etniska rensningar.[5] Men Sverige är väl ett lyckat exempel på humanism, kanske någon invänder. Det behövs dock inte speciellt stor analytisk förmåga för att se att bakom Högerns paroller om frihet döljer sig en stor egoism, och under Vänsterns rop om jämlikhet växer avundsjukans ogräs. Den oegennyttiga kärleken har ett pris och den trivs aldrig under samma hatt som kärleken till makt.

Ingen kan förneka att den moderna vetenskapen har förändrat och utvecklat samhället på både gott och ont. Men alla våra framsteg skapar nya problem. Den insiktsfulle Reichman menar att "En del oönskade verkningar av våra framsteg måste lösas genom tvång och kontroll. Ju mäktigare redskap människorna får i sin hand, desto strängare måste de övervakas, så att inte makten missbrukas. Redan härigenom leder vetenskapen på sikt till en utbyggnad av statsmakten över människorna. Vetenskapen leder till att byråkratin byggs ut. Gör man inte det kommer allt fler att missbruka vetenskapens frukter........ Men vem skall övervaka övervakaren?"[6] Kan humaniora fylla en funktion här? Och vilken slags legitimitet besitter vi för det?

Den moderna vetenskapen har alltså inte i tillräckligt hög grad tagit hänsyn till människans ofullkomlighet både vad gäller möjligheterna att uppnå den objektiva kunskapen och hennes tendens att missbruka det hon utvecklar. Kan vi tillämpa en annan insikt?

I den idag kanske vanligaste vetenskapliga normen kräver man att en empirisk utsaga skall genom observation med sinnena kunna bevisas eller motbevisas. Den skall stå öppen för prövning av något slag. Många menar att inget påstående om verkligheten kan vara meningsfullt om dess giltighet inte går att pröva genom observation. Om man godtar denna princip får man tillbakavisa varje så kallad metafysisk utsaga som meningslös. Är inte det ett typiskt utslag av vetenskapligt högmod? Många har dock ifrågasatt att de metafysiska utsagorna är meningslösa. Idag förefaller de flesta ha enats om att möjlighet till prövning, både verifiering och falsifiering, genom observation är ett kriterium för vetenskaplighet. En ovetenskaplig teori utifrån dessa kriterier är alltså inte nödvändigtvis meningslös. Detta 
vetenskapskriterium kan dock ifrågasättas och har så gjorts inom filosofin och gett inspiration till hela den postmoderna utmaningen. Den filosofiska insikten säger att vi inte med säkerhet kan bevisa någonting med våra sinnen. Därmed har man åtminstone på ett teoretiskt plan raserat den gamla skiljemuren mellan vetande och tro, och det är detta som har skrämt stora delar av den vetenskapliga världen. Den gamla grunden skakar när man inte längre med självklarhet kan dra upp gränser mellan prövbara och icke-prövbara teorier. Christer Winberg har tagit upp denna problematik i artikeln "Varför skriver vi inte historiska romaner istället?" Kuhns filosofiska insikt att teorier aldrig kan verifieras eller falsifieras har enligt Winberg öppnat dörren för kunskapsrelativism. Detta har i sin tur gett upphov till en identitetskris för historieforskningen.[7] Problemet som vi ser det är hur man skall finna nya samtalsformer för att inte hamna i total relativism där alla påståenden har samma värde.

I och med att den postmoderna kunskapsrelativismen och nihilismen har utmanat vetenskapssamhället framstår det ändå som nödvändigt att ta den utmaningen på allvar, ta till sig det som är bra, och frimodigt vräka det andra överbord. Alternativet till dagens vetenskapsortodoxi behöver dock inte vara den totala relativismen.

Den postmoderna relativism som förnekar den historiska objektiviteten/existensen är filosofiskt spetsfundig och ganska dum.[8] En sådan extrem ståndpunkt gör t ex oss historiker överflödiga. Det är i kretsar påverkade av ett sådant tänkande som man gärna och på allvar förnekar förintelsen av judar, zigenare, homosexuella och andra minoritetsgrupper under andra världskriget. Det är tragiskt, men vi lever i en tid där man måste argumentera för att förintelsen inte endast är en diskurs som finns i vår hjärna. För den som vill leka med ord är det förstås lätt att visa att förintelsen är en konstruktion. Eftersom inte alla judar dog kan vi inte tala om en verklig förintelse. Förintelsen är den beteckning vi har gett den tragedi som utspelade sig i Tyskland under andra världskriget. Problemet är att somliga även förnekar att miljontals människor mördades. Dessutom var katastrofen av en sådan omfattning att förintelsen visst äger sitt berättigande som en träffande verklighetsbeskrivning.

En annan extrem och lika dum ståndpunkt är uppfattningen som säger att konstruktionen av den objektiva historiska verkligheten är objektiv. Bäraren av denna idé förnekar därmed sin egen subjektiva inverkan på forskningsprocessen. Kanske menar han att källkritiken ger honom de redskap som möjliggör en absolut objektiv historieskrivning.

Den ståndpunkt som vi vill inta kan kort sammanfattas så här: Historien är objektivt verklig och har ibland lämnat vissa spår efter sig, spår som i sig själva ibland är både historien och konstruktioner men som vi oftast med källkritiska metoder kan värdera. Vi skriver sedan utifrån dessa spår av den förflutna verkligheten, samt sannolikhetsresonemang där källor saknas, ner en konstruktion, och denna konstruktions utseende påverkas av min samtid. Denna historieskrivning är alltså både objektiv och relativ. Historien i sig är något fast och givet - historien som skrivs är en berättelse, eller om man så vill, en historia om historien. Ofta kan vi med hjälp av källkritisk metod slå fast vissa händelser som fakta, även om det inte alltid är självklart. Men tolkningen och sammanhangen är ofta inte lika självklara och det är här som vi måste öppna upp för fler alternativa förklaringsmöjligheter och teorier. I en sådan historieskrivning ifrågasätts inte att förintelsen har ägt rum, men man ställer frågor som varför, hur det var möjligt och i vilket större sammanhang dessa händelser kan placeras in? Denna grundsyn innefattar således både tanken att det finns en objektiv sanning och verklighet, men också att vi människor inte på ett fullständigt sätt kan förstå och återge denna objektiva sanning och verklighet. Denna idé har en solid historisk och teologisk grundval. Den kristna kunskapsteorin hävdar att det finns en objektivitet i skapelsen och i Ordet, men att vi människor p.g.a. syndafallet inte äger fullkomlighet, vare sig när det gäller moral eller kunskap/förståelse. Detta uttrycks väl i Paulus ord "Nu ser vi en dunkel bild i en spegel. Min kunskap är ett styckverk." Denna insikt i människans ofullkomlighet borde göra oss mer generösa och öppna för i princip vilka teorier som helst. Sedan får forskarsamhället och allmänheten själva avgöra om de vill sätta tilltro till teorin. Problemet idag är att det finns mer eller mindre synliga gränser för vad man får säga och 
skriva i den akademiska världen och det gör att vetenskapen förlorar i kreativitet och profetisk skärpa.

\section{Humanioras profetiska uppgift}

En författare som har uppmärksammats för sina böcker och diagnoser av det moderna samhället är filosofen George Henrik von Wright. Nämnas kan böcker som "Vetenskapen och förnuftet", "Myten om framsteget" och "Att förstå sin samtid". Det är inte helt lätt att placera von Wright i en tradition. Han har själv uttryckt en förmodan att det framför allt är socialdemokrater, ledande ekonomer och vetenskapsmän som tycker illa om hans böcker, medan värdekonservativa och vänsterintellektuella kan tänkas uppskatta hans verk. Själv menar han sig emellertid inte känna sig hemma vare sig i det konservativa lägret med nostalgiska tillbakablickar, eller det vänsterintellektuella med sin överdrivna optimism. Von Wright kan väl närmast sägas vara en filosofisk samhällskritiker, eller som han själv säger, en provokativ pessimist.

I "Vetenskapen och förnuftet" liksom i "Myten om framsteget" ifrågasätter von Wright om den industriella produktionsformen är biologiskt lämplig för människan. [9] Han talar om "omständigheternas diktatur, en tvångströja som samhället ikläds av en accelererande och relativt autonom teknologisk utveckling och därav alstrad nödvändighet av oavbruten ekonomisk tillväxt och expansionism."[10] Han redogör sedan för framstegstankens historiska rötter och tillämpning, alltifrån Upplysningen och Franska revolutionen fram till vår tid.

I "Att förstå sin samtid. Tanke och förkunnelse och andra försök.(1945-1994)", får vi bland mycket annat typiskt nog en analys av kulturpessimisterna Oswald Spengler och Arnold Toynbee och deras betraktelser av olika kulturers uppgång och fall enligt schemat uppkomst-utveckling-förfall-försvinnande.[11] Och även om von Wright ställer sig tveksam och kritisk till en hel del av författarnas spekulationer, så är det ändå tidstypiskt att han dammar av gamla gubbar som Spengler och Toynbee. När Västerlandet upplever en allvarlig kris börjar människor undra om inte profeterna ändå hade rätt i sina pessimistiska analyser. Profeterna själva är då oftast döda. Profeter blir sällan långlivade. I Gamla testamentet finner vi urtypen för en profet. Profeterna i GT gick till hårt angrepp mot tidens missförhållanden och orättvisor, och hotade med att samhället skulle gå under om inte folket bättrade sig och vände om till Gud. Budskapet var inte populärt och profeterna blev ofta slitna i skäggen, nedkastade i brunnar eller dödade. Folket lyssnade hellre på de profeter som beskrivs som falska - de som sade "allt står väl till, allt står väl till."

Vad vi vill säga med detta är att humaniora borde kunna utveckla en profetliknande tjänst i samhället där vi i något högre grad än idag går mot strömmen, sjunger falskt, utmanar, kommer med oväntade teorier och ställer obekväma frågor.

\section{Phronesis}

Vi menar att det finns en väl underbyggd uppfattning om och känsla av att den västerländska civilisationen genomgår en kris som har många dimensioner. Idén om Västerlandets kris är emellertid ingen ny företeelse under 1900-talet. Redan vid seklets början, i synnerhet i och med första världskriget, fanns det dom som framlade apokalyptiska framtidsvisioner för vår del av världen. Inte minst olika kristna grupper framförde tankar om den yttersta tiden, anti-krist och den nära förestående domen.

Bland de mer kända filosoferna kan nämnas Oswald Spengler och hans bok "Västerlandets undergång", som började skrivas redan före första världskriget men vars första del publicerades 1918. Spengler ger uttryck åt en cyklisk historiesyn. Han menade att kulturer "föds, växer, mognar, kulminerar, vissnar och går under."[12] Han vänder sig mot framstegsoptimismen och den konventionellt linjära synen på historien, men också mot den västerländska etnocentrismen. Han använder sig i sin analys av motsatsparet kultur - 
civilisation. Kulturen representerar den fruktbara och skapande åldern. Det är då som religionen, filosofin och konsten frodas. Sedan stelnar kulturen plötsligt och dör bort - den blir civilisation. Spengler menade att den moderna västerländska kulturen var på väg in i sitt förstelningsstadium, in i civilisationen.[13]

Nästa våg av krismedvetenhet kom i samband med den stora ekonomiska kraschen och depressionen runt 1930.

Den tredje fasen kom under och efter andra världskriget, då allt vad mänsklighet är ställdes på sin spets.

Nu upplever vi den fjärde vågen där miljöförstöring, kronisk arbetslöshet, ensamhet, våld, vetenskapens etik och mycket annat står i fokus. De senaste 20 åren har man allt oftare talat om moderniseringens faror. Den empiriskt bevisbara miljöförstöringen har medfört att många röster hörs som ifrågasätter om det industriella produktionssättet är förenligt med de villkor som naturen ger för biologiskt liv. Problemet är givetvis oerhört komplicerat, inte minst eftersom miljontals människor är helt beroende av miljöfarliga industrier för sin egen överlevnad. Likaså finns det en kritik som mer inriktar sig på de psykiska och andliga dimensionerna av mänskligt liv. "Konsumtionskulturen skapar ytlighet och vulgarisering. Förlusten av traditionella auktoriteter och värden gör att vi mister vår förankring i tid och rum. Rotlösheten leder till främlingsskap och aggressivitet. Den moderna psykoterapin skapar inte stabila ansvarskännande personligheter utan egoistiska njutningsmänniskor. Våld och otrygghet frodas i det kaos som uppstått sedan vi förkastat de värden som tidigare höll oss samman,"[14] skriver Lennart Lundmark i en artikel i Svenska Dagbladet.

Även om vi till äventyrs skulle kunna komma överens om att dagens samhälle upplever en kris, så är det inte säkert att vi kan bli eniga om krisens natur. När man i den politiska debatten talar om kris åsyftas ofta sådana förändringar som i ett längre tidsperspektiv framstår som marginella och som normala variationer i cykliska konjunkturer. För ett företag eller för den enskilda människan kan förstås en lågkonjunktur vara ett hårt slag, men den hotar inte hela samhället eller kulturen. Efter de sju magra åren kommer sju feta.

Men det finns alltså de som menar att hela den västerländska kulturen befinner sig i en ödesdiger situation. Förutom krissymtomen i sig har det kommit en mängd artiklar, böcker, rörelser och partibildningar[15] de senaste åren som ger uttryck för denna tanke. Någon systematisk genomgång av detta presenterar vi inte här.

Så olika tänkare som Max Weber, Michel Foucault och Jürgen Habermas har iakttagit att den instrumentella rationaliteten under mer än två århundraden i allt högre grad har dominerat över värderationaliteten, vilket har lett till uppkomsten av det som kallas en civilisation av medel utan mål.[16] Det väsentliga är dock inte att de stora tänkarna har insett detta, utan att de flesta människor har konkreta vardagserfarenheter av fenomenet (våra handtagslösa fönster!) Den instrumentella rationaliteten är skadlig om den tillämpas ensidigt, och enligt Weber tog sig konsekvenserna uttryck i vad han ansåg som alienation och ett undergrävande av traditionella värden som bidrog till en allmän vantrivsel i världen. "Efter Weber har dessa konsekvenser av allt att döma blivit tydligare och under de senaste årtiondena har det tillkommit ett helt nytt problemkomplex med anknytning till ekologin och naturen, som utgör en mycket allvarlig fara för själva den levande världens existens oavsett om den vantrivs eller inte", skriver Bent Flyvbjerg.[17] Finns det något som kan komplettera denna ensidighet?

Bent Flyvbjergs avhandling "Rationalitet og magt", liksom hans artikel "Vårt behov av Phronesis", tog oss med storm. Det Flyvbjerg gör är att han försöker förnya forskningens meningsfullhet genom att ställa väsentliga frågor som - vart är vi på väg, vem tjänar på det och vem förlorar, är det önskvärt, vad bör göras? Flyvbjerg tar sin utgångspunkt i Aristoteles resonemang i "Den Nichomakiska etiken" där han behandlade den samhälleliga betydelsen av det han kallade intellektuella dygder, speciellt de tre dygder som benämns episteme, techne och phronesis. 
Termerna episteme och techne finns fortfarande i det moderna språket, $\mathrm{t}$ ex i ord som "epistemologi" (kunskapsteori), "teknologi" och "teknisk", medan det är svårt att finna någon direkt modern motsvarighet för phronesis. Episteme åsyftar närmast en fix universell kunskap. Techne rör produktionen av ting, skapandet, medan phronesis rör handlingen och dess förhållande till sådant som är bra eller dåligt för människan. Phronesis är den sorts kunskap och förnuft som utgör grunden för praxis. Phronesis kräver eftertanke och omdöme. Under den rationalistiska utvecklingen de senaste två till tre seklen har phronesis och värderationalitet blivit marginella företeelser.

För många är det gängse synsättet att vetenskapens själva identitet och existensberättigande ligger i det epistemiska idealet där det gäller att exakt avgöra det som är absolut säker och universell kunskap. Flyvbjergs erfarenhet är att "i många akademiska sammanhang är prestigen, pengarna och makten avhängiga av att detta synsätt godtas.[18] En förnyelse av humaniora borde innefatta en utveckling av Phronesis.

Vad Flyvbjerg inte tar upp till diskussion är människans inre natur. Har människan verkligen en förmåga att göra världen bättre bara för att vi tänker mer phronesis? Utifrån en kristen grundsyn och historisk erfarenhet är människan oförmögen att i egen kraft göra världen god. Kristendomens kärna är förvisso inte dess etik utan Jesus och hans försoningsverk. Likväl är den kristna etiken en av de viktigaste frukterna av tron och det är en grundläggande tanke och kanske en paradox i kristen lära och praxis att människan ändå skall leva efter en slags grundläggande skapelseordning som innebär att man för släktet vidare och arbetar för den stads bästa där man bor. Det finns i den kristna grundsynen ett trotsigt hopp, trots allt.

Phronesis som en möjlig utgångspunkt för samhällsforskningen har vi mött tidigare, t ex hos kultursociologen Mats Trondman på Centrum för kulturforskning i Växjö, då som en uttalad inlevelseinriktad hållning i forskningsprocessen, som en vilja till att låta sig överraskas och en ambition till att låta värden finnas med i eventuell teori- och metodanvändning. Det här påminner starkt om Flyvbjergs uppmaning till att låta den konkreta undersökningen, så detaljrikt som möjligt, själv ge svaret, liksom uppmaningen till att ta med den etiska dimensionen. Vi vill betona att det inte är frågan om att det inte skulle finnas någon "teori-impregnering" med Phronesis-tanken (det kommer vi till lite längre fram!).

Det finns naturligtvis skillnader i teori-användning mellan t ex samhällsvetare och historiker, något som t ex Ingvar Johansson och Peter Burke påpekat. I våra ögon är den teori-användning som sociologerna står för, betydligt mer instrumentell och metodologiskt inriktad än inom historieämnet, men framförallt är teorianvändandet mycket "bourdieanskt" - d v s som en form av facklig "tranedans", vars främsta syfte är att legitimera facklig tillhörighet. Med det vill vi inte säga att historikerna inte skulle ha "tranedans", tvärtom, men den kanske tar sig andra uttryck - som t ex i ett nödvändigt accepterande av kausaliteten för den historiska "utvecklingen"?

Vad som är förvånande (såvitt vi kan bedöma och inte minst med tanke på hur mycket lovord som kommit Flyvbjerg till del från de mest skilda ämnen!) är att en Phronesisinriktning ändå tycks ha det motigt att få fäste i forskarsamhället i praktiken. Nog borde det t ex kunna finnas behov av en mer "mikrohistorisk" eller antropologiskt inriktad forskning, kanske särskilt av ett lokalhistoriskt perspektiv? Alla (nästan?) kan säkert skriva under på det närmast idealistiska inslaget i en sådan här inriktning (idealism i dess mänskligt/positiva, inte dess vetenskapliga betydelse!). Men kanske det är här, i uppmaningen till engagemang, som problemet delvis ligger? Vi reagerade själv så - hur skall man få det nisch-tänkande och polemik-undvikande forskarsamhället av idag att svara på en sådan uppmaning - varefter vi genast blev mycket missmodiga. I stället får vi väl vänta på att en avhandling dyker upp som tar upp handsken litterärt åtminstone, d v s om ca 8-10 år?

En delförklaring till vårt missmod och känslan av "hopplös idealism" hos Flyvbjerg, kan 
kanske sökas i Kuhns paradigm-teori. Det intressanta för oss är inte huruvida det förekommer likartade paradigmer inom naturvetenskap och sam/hum. Här tror vi att "delparadigmer" kan ge en bra bild av paradigm-funktionen inom sam/hum i dag. Men ovanstående leder oss spontant till Pierre Bourdieu och hans fältbegrepp.[19] Vi kanske går för långt, men som vi tolkar Bourdieu, så kan hans fältbegrepp användas som en form av paradigm-begrepp, där den inre dynamiken, liksom de revolutionära förändringarna aldrig tillåts hota fältets existens - det är där vi upplever att ett eventuellt paradigm kan finnas, både som livsfält för deltagarna (löner, status o s v) och som intressefält (ideologi, kunskapssyn, vetenskapssyn o s v).

Hur tolkar vi då paradigm-begreppet? Här är vi delvis "feyerabendska" och tolkar paradigm som ett "ideologiskt arv" som inte i princip förändrats sedan antiken. Det här arvet har inte fått sin nuvarande status som global diskurs, förrän efter västeuropas tidigmoderna och alltmer succéfyllda expansion - den är $\mathrm{m}$ a o en uttalad form av "segrarnas diskurs". Innan dess fanns det konkurrerande/oberoende diskurser/paradigm, d v s västeuropeiskt opåverkade kulturer. Vi tror också att Paul Feyerabend har helt rätt när han uppmanar till teoretisk och metodologisk pluralism.[20] För det är kanske i detta som dagens "diskurs-alternativ" kan finnas: sub-kulturer, ursprungs-ideologiska motståndsfickor (indianer o s v), eko-rörelser, teologisk världs- och historiesyn eller "flum" som New Age (just New Age har vi personligen svårt för i dess uttalade elitism och mycket pretentiösa självsyn, men det kan väl delvis också känneteckna den etablerade vetenskapen, åtminstone när den ifrågasätts?).

En annan viktig fråga för oss, som delvis kan kopplas till den förda diskussionen, är tidens betydelse. Tiden som ett "historiskt fenomen" tror vi kan vara väsentlig att undersöka/problematisera, framförallt som linjär historie- och livsuppfattning. Med all sannolikhet har det linjära perspektivet en viktig grund i det mänskliga livets livsgång, att den mäts med kroppens "ändliga uppgång och fall" som måttstock. Men det finns troligen också, som t ex Lennart Lundmark med kraft påvisar, en stark social/ekonomisk och samhällelig koppling till den linjära tidsuppfattningen.[21]

Här finns en för oss mycket intressant fråga - vilka alternativa roller kan det mänskliga livets (ca) 60-70-åriga tidsspann ha som mall för den individuellt omfattade historie- och världssynen? Här kan kanske t ex antropologin bistå med alternativa tolkningar, från kulturer där människans nu är basen, där det förflutna och det kommande endast är breddningar av nuet?[22] En sådan "praxis-centrerad" livshållning framstår, för oss i alla fall, som betydligt mer "verklighetsnära". Det var också ett ganska tydligt drag i den "lägre" arbetarkultur Kenneth växte upp i - "var dag är sin egen plåga" - och i den tjänandets vardagskristendom som Jonny har sina rötter i. A andra sidan är det inte nödvändigtvis så att denna "tidlösa" anda endast behöver vara ett "subfenomen" - på en individuell nivå kan den kanske rentav vara allmänt förhärskande?[23]

För att göra en grov bild av vad vi menar, så använder individen historien/berättelsen som en fördjupning av nuet - det är inte det förflutna som primärt görs meningsfullt utan det nuvarande! På det här planet kan vi se individerna som centrum för en personlig skapelseprocess, som likt ringar i vattnet sprids ut och "erövrar" individens närområde/livssfär. Varje berättelse kan ses som "ny". Vad vi har gemensamt är det historiska råmaterialet till att bygga våra berättelser/livshistorier. Det här behöver inte ses som ett begränsat fenomen. I själva verket tror vi att t ex historikers verksamhet i grunden har samma syfte och funktion! Strukturerna, de kausala konsekvenserna, skulle i så fall kunna kännetecknas av en betydligt större slumpmässighet, (Jonny vill inte använda ordet slump utan hänvisar mer till människans oförmåga att kunna se orsaker och hela sammanhang) av icke-planering än vad vi riktigt vågar erkänna? I det sammanhanget blir praxis en form av allmän mänsklig manipulering, en manipulering som alltid förändrar, lägger till och drar ifrån, så att slutresultaten av de mänskliga projekten mycket sällan blir vad som ursprungligen tänkts.

Varför är det så förbenat svårt att uttrycka dessa tankar? Vi tror att det beror på att vi här 
har det kanske klaraste och bästa exemplet på den paradigmatiska berättelsens funktion det finns helt enkelt knappt ett språk att uttrycka det på! Men, och här kan vi återkoppla det till Flyvbjergs Phronesis, i praxis finns det kanske, som uttryck för praktiskt vardagshanterande? För att komma nära vardagens nu-funktion, krävs det förmodligen att vi tonar ner den teoretiska för-förståelsen och blir mer ödmjuka gentemot människorna och även mer lyhörda, därför att det är i handlande och inte i första hand i språk som detta uttrycks, även om språk är viktigt. Detta är något som för våra avhandlingsarbeten känns oerhört centralt, eftersom vi båda vill fokusera huvudsakligen en skriftlös grupp människor (skriftlös/historielös som majoriteten av svenska folket runt sekelskiftet 1900, liksom även idag), en grupp som i bästa fall figurerar i andras, de offentligas berättelser.

Den postmoderna utmaningen, framförallt med Den Stora Berättelsens sammanbrott, förtjänar att tas på högsta allvar. Men frågan är om denna utmaning tjänar till en "befrielse" eller skall ses som uttryck för att Paradigmet utökar sina domäner/fördjupar Berättelsen?

Vi har tidigare argumenterat för att en förnyelse av humaniora inte behöver betyda att vi accepterar kunskapsrelativismen. Däremot måste vi våga diskutera olika djup och betraktelsesätt när vi vill belysa fakta och sanningar. På det teoretiska planet så kan man fråga sig vad en kunskapsteoretisk relativism, (vilket inte är det samma som kunskapsrelativism) skulle innebära konkret? Vilka blir konsekvenserna? Vi vet faktiskt inte! Bör man inte hellre fråga vilket perspektiv den har som är bekymrad över detta? Borde inte den personen klarare definiera konsekvenserna! Är det kanske endast frågan om ett kunskapsbärande skikts rädsla för att tappa sitt hegemoniska tolkningsföreträde, eller är det begynnelsen på en västeuropeisk Kulturskymning, en inledning till den Slutgiltiga Barbarin?

Slutligen så vill vi poängtera att den "källkritiska" inställningen naturligtvis måste vara den ledande principen för det historiska berättandet - men på något sätt är den väl närmast självklar? Kritiken mot den gamla positivismen var väl delvis riktad mot det konsekventa utelämnandet av den svårtolkade och käll-lösa historien; att det lilla som kunde accepteras som solida fakta inte betraktades som "minimalistiskt" och som ett styckverk, utan tilläts att dominera och förklara allt det som måste uteslutas? Det är i alla fall en tolkning som vi gör. Alternativet till "den gamla skolan" - 60- och 70-talens marxism - vände i princip på detta. Med sin helt förklarande teoretiska "mall", kunde man på ett omvänt sätt göra en likartad "överhoppning" av all den historiska praxis som utspelade sig i "basen".

Det ovanstående blir ännu en motivering till varför vi tror att det är så viktigt med en ödmjukare inställning hos vetenskapen gentemot människan, att vi i högsta grad behöver mer Phronesis.

\section{Avslutning}

Vetenskapen har de senaste århundradena bidragit till att förändra hela vår värld i ett rasande tempo - på både gott och ont. Bristande insikter i människans ofullkomliga väsen har ofta gjort att utvecklingen har gått snett när vetenskapen skulle tillämpas. Och någonstans på vägen förlorade forskarna kontakten med både himmel och vardagsliv, vilket har gjort vetenskapen mer smal och inskränkt än vad som är nödvändigt. Vi har försökt peka på en möjlig förnyelse av humaniora både i mer existentiell och vardagligt praktisk betydelse. Vi har argumenterat för att öka den teoretiska mångfalden och återupprätta de värden som sammanfattas i begreppet phronesis. Hela resonemanget grundar sig i att människan borde inta en mer ödmjuk inställning till verkligheten, helt enkelt därför att verkligheten är så stor att vi i vår ofullkomlighet aldrig kan fånga hela sanningen. Denna ödmjuka inställning är dock inte tänkt att leda till intellektuell slapphet där vi inte vågar argumentera utifrån en övertygelse om att något är sant och rätt. Det innebär inte heller att vi utan vidare tror på helande kristaller eller gröna gubbar från Mars. Men vetenskapen borde våga öppna upp för fler teorier, metoder och frågeställningar. Med en dialogisk grundhållning, utvecklandet av argumentationsteknik, källkritik och kärleksfull generositet så borde det vara en framkomlig väg. 
Det lönar sig inte att riva gärdsgårdarna. De ruttnar av sig själva med tiden. Samtidigt bygger vi nya, men de är förhoppningsvis inte så stabila som de som byggdes på 1700talet. Förhoppningsvis får vi också snart fönster med handtag på - så att vi slipper krossa rutorna.

\section{Jonny Nilsson och Kenneth Strömberg, doktorander i historia vid Lunds universitet, verksamma vid Högskolan i Växjö.}

[1] Reichman, Sven, 1989, Från Nimrod till Antikrist. Bok 2 i serien Historiens Gud. Sid

90.

[2] Ibid sid 91.

[3] Ibid sid 92

[4] Ibid sid 94

[5] Hoppas ingen tar illa upp av hänvisningar till Gud. Om någon ändå gör det så vore det intressant att diskutera huruvida det beror på rent personliga åsikter, eller är en frukt av det vetenskapliga systemet.

[6] Reichman, aa, sid 192f.

[7] Winberg, Christer, 1990, "Varför skriver vi inte historiska romaner istället? Ett

debattinlägg om historikerns förhållande till verkligheten." I Scandia 1990:1.

[8] Postmodernisten framstår, precis som alla vi andra, som en fundamentalist när han med frenetisk energi hävdar "sanningen" att all sanning är relativ eller att den inte ens finns. Ett sådant påstående bygger som allt tänkande på en grund - ett fundament.

[9] Wright von, George Henrik,1993, Myten om framsteget, sid 8.

[10] Ibid, sid 10.

[11] Wright von, 1994, Att förstå sin samtid, sid 135ff.

[12] Nordin, Svante, 1995, Från tradition till Apokalyps. Historieskrivning och civilisationskritik i det moderna Europa, sid 131.

[13] Ibid, sid 130ff. Se även Alf Ahlbergs bok om Spengler som heter Västerlandets undergång, liksom Georg Henrik von Wrights bok Att förstå sin samtid, där han bl a tar upp Spengler och Arnold J. Toynbee, sid 135ff.

[14] Lundmark, Lennart, "I dag skapas ständigt nya auktoriteter och traditioner" i: SvD 7/896.

[15] Jag åsyftar främst miljörörelsen och de s.k. gröna partierna, som väl får betraktas som seriösa.

[16] Flyvbjerg, Bent, 1994, "Vårt behov av Phronesis". I: Om 3, 1994.

[17] Ibid, sid 49.

[18] Ibid, sid 49.

[19] Bourdieu, Pierre, 1991 (1984), Kultur och kritik.

[20] Feyerabend, Paul, 1975, Against method.

[21] Se t ex Lundmark, Lennart, Det förflutnas makt - Om sociala tidsbegrepp och samhällsförändring. Eller: Tidens gång och tidens värde, av samme författare.

[22] En mycket inspirerande bok i detta sammanhang är The American Indian and the

Problem of History, 1987, ed Martin, Calvin. I den ingår en rad artiklar som tematiserar den stora metafysiska väsensskildheten mellan västerländskt historiemedvetande ("tidsfångenskap") och den organiskt-kosmiska nu-tillhörigheten hos de nordamerikanska indianerna. Som en viss röd tråd, framstår nödvändigheten av att vi lär av dem! Nu vill vi inte med detta hävda att det skulle finnas ett bestämt metafysiskt hållningssätt hos indianer eller att det inte kan finnas inslag av "den vite mannens" romantiserande av indianska traditioner! Se även ett mer principiellt utvärderande av denna fråga i Calvin, Martin In the Spirit of the Earth. Rethinking History and Time, 1992.

[23] Att dessa frågor har fått stor aktualitet, visas av t ex Chartier, Roger, On the edge of the cliff, 1997. I den framhävs t ex den individuella historieskrivningen och det individbaserade korta tidsspannet. 